\title{
Toxocara Canis infestation with encephalitis
}

\author{
NADIA Z. MIKHAEL, VITAL J. A. MONTPETIT, MANUEL ORIZAGA, \\ HARRY C. ROWSELL, MICHAEL T. RICHARD
}

\begin{abstract}
SUMMARY: The syndrome "visceral larva migrans" produced by migration of nematode larvae (commonly Toxocara species) in the extraintestinal tissues in unusual hosts, including man (particularly children of dirt eating age), with the production of reactive granulomatous lesions, was first described in 1952. About 200 cases have been reported since. Well documented cases are rare due to the difficulty in histological verification. Three cases have been reported in Canada but these were
\end{abstract}

RESUMÉ: Le syndrôme "visceral larva migrans", causé par la migration de larves nématodes (le plus fréquemment de l'espèce toxocare) dans les tissus extra-intestinaux et qui se développe, accompagné de lésions granulomateuses réactives, chez des hôtes inhabituels, y compris l'homme (particulièrement les enfants a l'âge où ils mangent salement) fut décrit pour la première fois en 1952. Bien que deux cents cas aient été dénombrés depuis, la vérification en histologie étant difficile, les rapports précis demeurent rares. Au Canada, on rapporta trois cas, mais aucun de ceux ci ne fut vérifié. Nous pensons que celui not verified. We believe the present report is the first verified case of visceral larva migrans in Canada and the fifth case of human cerebral involvement by Toxocara in the English literature. It is hoped that this report will emphasize the need for further research into the role of host versus parasite and will underline the potential danger, albeit remote, of household pets to children. Indeed, prevention is the only line of attack, as there is no effective drug against the migrating larvae of Toxocara.

rapporté ci-dessous est le premier cas connu au Canada dont la vérification a prouvé la présence de larva migrans, et le cinquième cas d'atteinte cérébrale par Toxocara décrit dans la littérature anglaise. Nous espérons que ce rapport servira à mettre l'accent sur le besoin de recherche supplémentaire dans le domaine des relations hôtes-parasites, et à souligner le danger potentiel, quoique vague, que représente la cohabitation enfants-animaux domestiques. La préventation reste donc notre seule ressource, étant donné qu'il n'existe aucun médicament efficace contre les larves migrantes de la Toxocara.
From the Department of Pathology, University of Ottawa, and the Departments of Laboratory Medicine and Neurosurgery of Ottawa General Hospital.

Reprint address: N. Z. Mikhael, M.B., B.Ch., Department of Laboratory Medicine, Ottawa General Hospital, Ottawa K1N 5C8 Ontario, Canada.

\section{INTRODUCTION}

Toxocara canis, the common roundworm of the dog, is harmful to man and is a public health problem. There is a large reservoir of Toxocaral infestation in dogs in many countries, including Canada. The incidence of Toxocariasis in Canada is unknown but is probably commoner than this single case report indicates. The prime difficulty in this infestation is that it gives rise to larvae which migrate in the tissues but do not develop beyond the second stage in man. The larvae are small, and because as few as 20 may cause significant illness, it is certain that in most cases it will be difficult to diagnose the infestation by recovering the larvae. A prolonged search through many serial sections is usually necessary to locate a larva and even then, only a transverse section at the level of midgut is conclusive evidence. Larvae were identified in our case after examining 300 sections. It is the object of this paper to report a fatal case of Toxocariasis. This is the first known verified case of visceral larva migrans in man in Canada and the fifth case of human cerebral involvement by Toxocara in the English literature.

\section{CASE REPORT}

An 18 month old white male was admitted to hospital with fever of unknown origin and nasal catarrh of one week's duration. The child was the first born after an uneventful pregnancy and delivery. During infancy he suffered only occasional colds and had no major illnesses. He had been found eating dirt on numerous occasions in the yard. The family had no household pets.

On his first admission the child was pale, with a temperature of $101^{\circ} \mathrm{F}$ and a 
slightly enlarged spleen. His hemoglobin was $7.2 \mathrm{gm} \%$, WBC was $32,000 / \mathrm{mm}^{3}$ with an eosinophilia of $64 \%$. X-ray of the chest showed streaky, abnormal shadowing in the right upper and both lower lobes. A few days after admission, rhonchi were heard in the chest and his leukocyte count went up to $45,000 / \mathrm{mm}^{3}$ with no change in the differential. He was treated with Ampicillin and ferrous sulphate and showed some improvement, but his eosinophil count was unchanged. The clinical impression at the time of discharge was that of iron deficiency anemia, and possible visceral larva migrans.

He was re-admitted 3 weeks later in a semicomatose state with a 10 day history of shaking spells and ataxia. He repeatedly went into status epilepticus and was transferred to the Ottawa General Hospital. On arrival, he was comatose, but responded to some stimuli and was able to move all four limbs. There was no neck rigidity. His pupils were small, equal and reactive to light. Pulse rate was between $120-140$ beats/ minute. Blood pressure $120 / 70$ and temperature $101^{\circ} \mathrm{F}$. Examination of the heart and chest revealed no abnormalities. The liver was palpable $2 \mathrm{cms}$ below the right costal margin; the spleen was just palpable. The reflexes were physiological. Laboratory data were as follows: Hemoglobin 10.4 , hematocrit $36 \%$, WBC $9,100 / \mathrm{mm}^{3}, 42 \%$ Neutrophils, $40 \%$ lymphocytes, $4 \%$ monocytes, $10 \%$ basophils and $4 \%$ eosinophils. The platelet count was normal. Urine analysis was normal. CSF sugar was $88 \mathrm{mg} \%$ and protein $320 \mathrm{mg} \%$. The electroencephalogram was abnormal with focal abnormalities in the left hemisphere behind the Sylvian fissure and in the right fronto-temporal area. A repeat record showed similar changes in the left posterior frontal region. Echoencephalogram showed no shift. Burr hole exploration and left carotid angiography were normal. Liver biopsy showed two granulomata of uncertain etiology. The convulsions were only temporarily controlled by anti-epileptic agents. His general condition remained poor and he died 3 days after his second admission and 7 weeks following his first admission.

\section{PATHOLOGICAL FINDINGS}

Most of the organs revealed mild organomegaly; the liver weighed 440 gms, the spleen $60 \mathrm{gms}$, the heart 60 gms and the pancreas $30 \mathrm{gms}$. There were multiple, firm, grey-white nodules up to $0.3 \mathrm{~cm}$ in diameter in the liver and heart and an occasional focal hemorrhagic area $0.4-0.5 \mathrm{~cm}$ in diameter in the lungs, pancreas and spleen. Microscopic examination of these lesions revealed granulomata in various stages of evolution. Typical Toxocara canis larvae were identified in the liver, heart and brain.

The lungs revealed considerable atelectasis and extensive pulmonary edema with patchy bronchopneumonia. Scattered throughout many sections were granulomata consisting of a central area of necrosis surrounded by palisaded epithelioid cells and a dense infiltrate of eosinophils, neutrophils, lymphocytes and plasma cells. Some of these granulomata contained multinucleated giant cells and were surrounded by a concentric layer of collagen fibers. These represented lesions of longer duration.

The heart showed rounded or elongated granulomata with darkly eosinophilic centers containing large amounts of cellular debris surrounded by mononuclear cells of epithelioid type together with multinucleated giant cells. Older granulomata as described in the lung were also seen. One early lesion con- tained an oblique section through the intestinal region of a Toxocara larva.

The valves were normal. The epicardium was edematous and contained scattered foci of neutrophils, eosinophils and mononuclear cells. Similar changes were also seen in the myocardial septae.

In the liver, the granulomata were numerous and scattered in an irregular fashion. They showed central, complete, destruction of liver cells and collapse of reticulum framework, often with "fibrinoid" alteration of individual fibers. Around the center there was the usual dense exudate of eosinophils, histiocytes, rare plasma cells and occasional giant cells. Older granulomata with many giant cells surrounded by a layer of collagen fibers were also seen. Many early lesions displayed portions of second stage infective larvae of Toxocara canis (Fig. $1 \&$ 2). The diagnosis was made on the basis of the characteristic structures of the transverse section of the larva at the midgut level, namely: diameter $18-20$ micra, prominent single lateral alae, single intestinal cell, and large, well defined posterior excretory columns occupying a greater proportion of

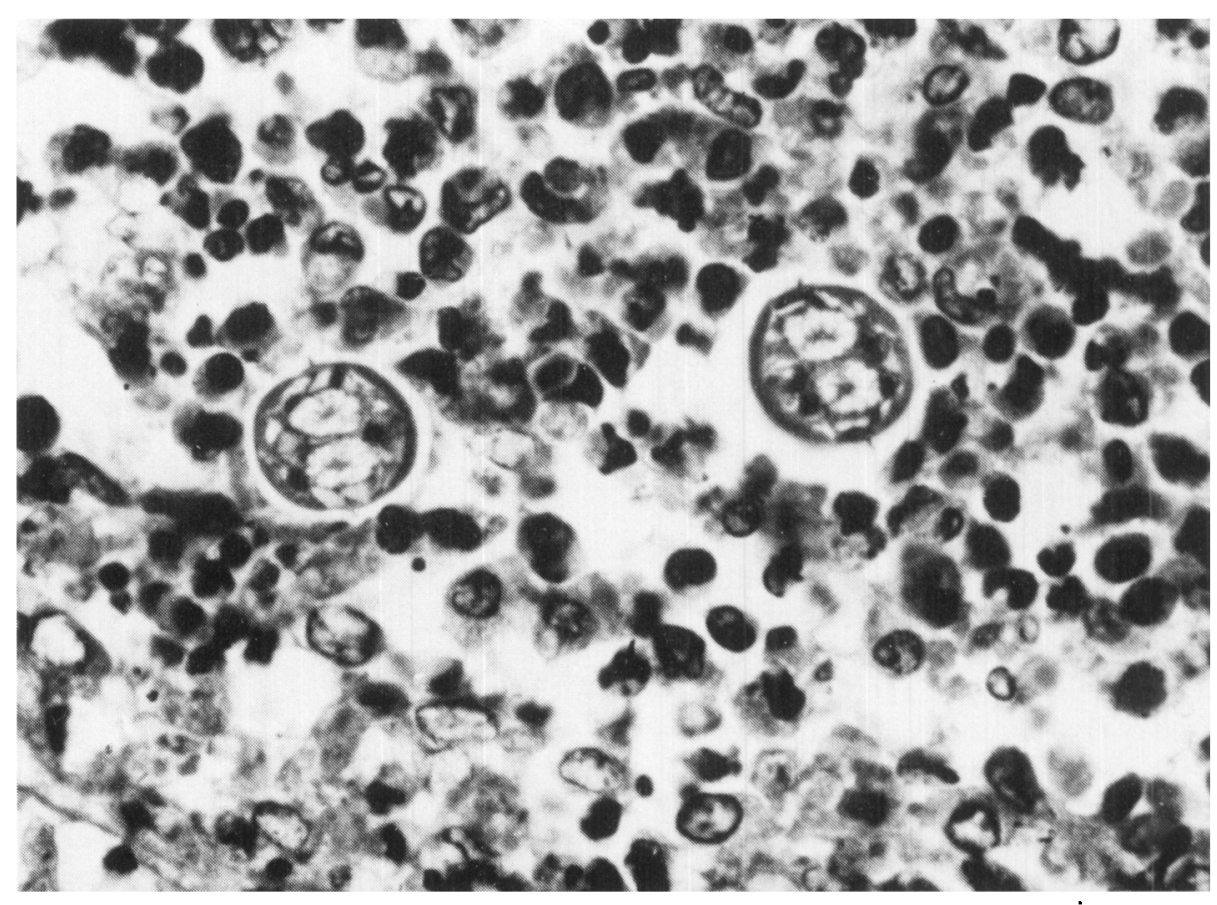

Figure 1. Sections of Toxocara canis larvae at the level of midgut with necrotic debris and inflammatory cells in a granuloma of the liver. Note the prominent single lateral alae, single intestinal cell and large well defined posterior excretory columns. HPS x 750. 


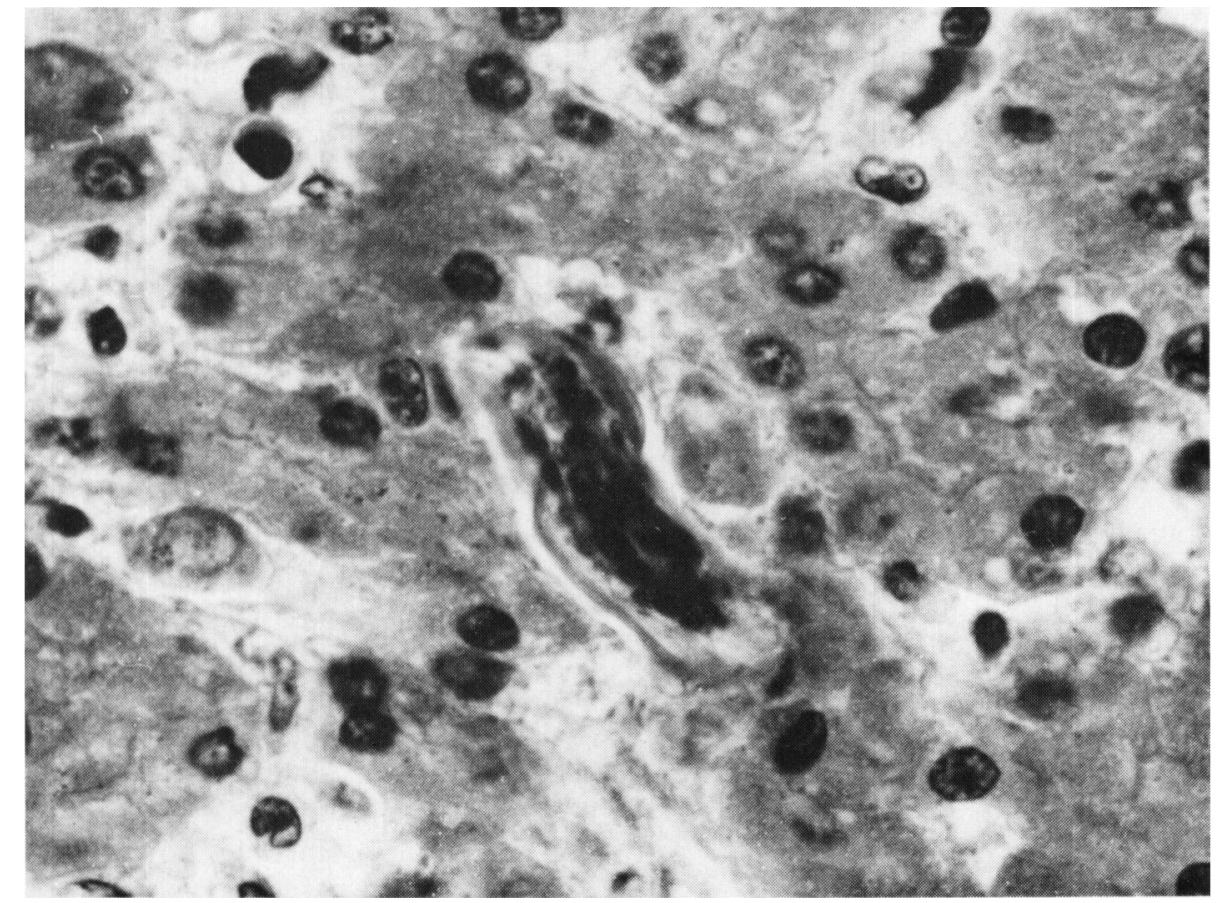

Figure 2. An oblique section through the densely nucleated intestinal end of the nematode larva in a sinusoid of the liver.

HPS x 750 .

the body cavity than the intestine (Fig. 1).

The pancreas and spleen showed multiple granulomata similar to those seen in the liver.

Throughout the cerebral hemispheres, cerebellum and brain stem, there were multiple, small, sharply demarcated regions of granulomatous inflammation involving both grey and white matter. These appeared to be more recent than those in the visceral organs, being composed almost entirely of epithelioid cells. In the center of most of these, parts of the coiled nematode, cut in various planes, were observed (Figs. 3, 4, 5).

\section{DISCUSSION}

During the past decade, the recognition of Zoonoses, "those diseases and infections which are naturally transmitted between vertebrate animals and man", as defined by the World Health Organization, has been one of the advances in Medicine. The dog "man's best friend" is said to have been domesticated about 60,000 years ago and is the one animal which enjoys a closer association with man than any other. The daily social contact with this pet, especially with children, is conducive to the trans-

HPS x 120 .
Toxocara canis, the common roundworm of the dog, is harmful to man and is a public health problem. Man may act as host of these parasites. The ingestion of eggs may result in the migration of Toxocara larvae through the somatic tissues, and subsequent encystment and granulomatous lesions in the various organs of the body.

The syndrome was first defined by Beaver et al (1952). Visceral larva migrans is usually due to the most commonly occurring ascarid species, Toxocara canis or Toxocara cati, the roundworms of the dog and cat respectively. Usually it is a relatively benign disease characterized by sustained eosinophilia of $30 \%$ or more, hepatomegaly, fever, anemia and pneumonitis. Although the syndrome occurs more frequently in children, adults appear (Snyder, 1961) to be susceptible, but are less commonly infested because of better personal hygiene (Dent et al, 1956).

Since the syndrome was first described about 200 cases have been reported (Woodruff, 1970), but well documented cases are rare. In Canada, two cases were reported by

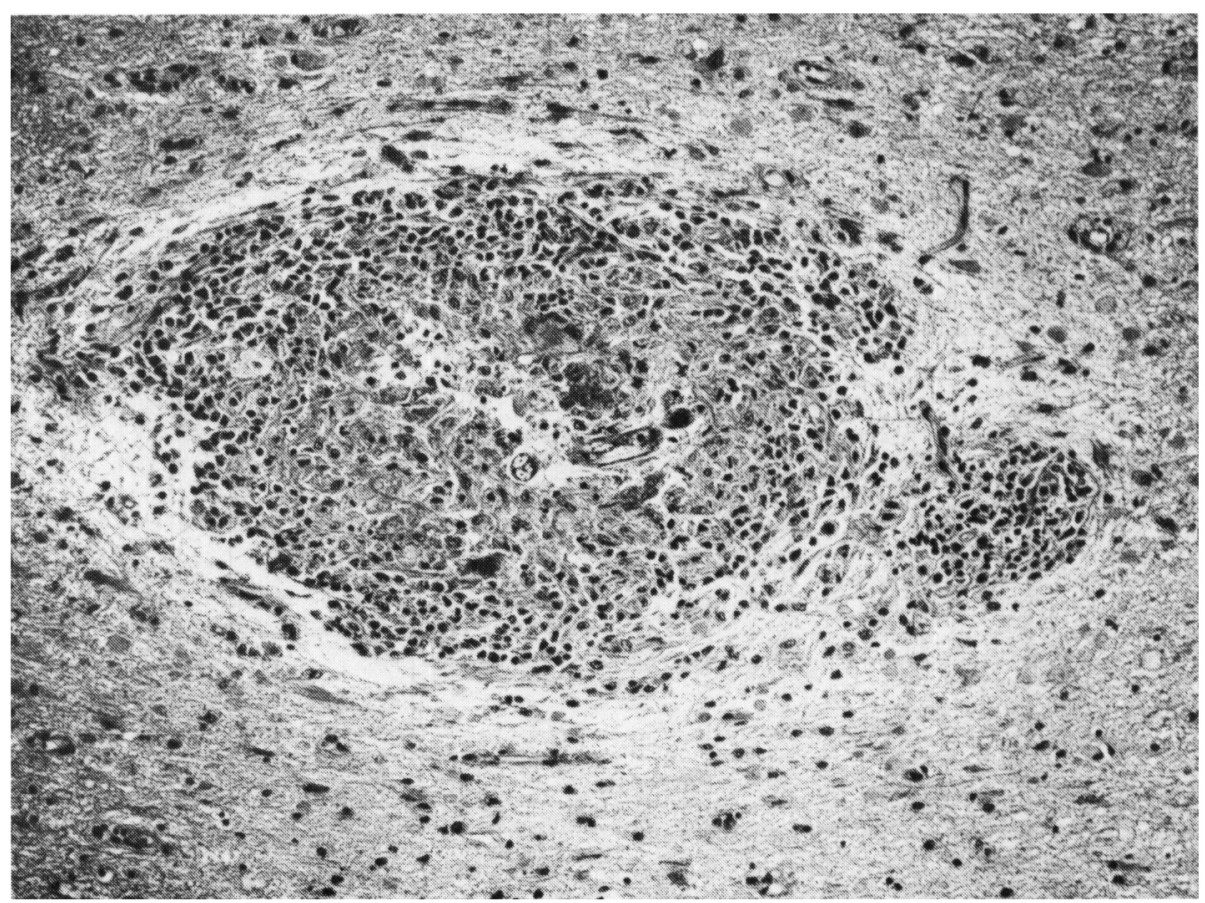

Figure 3. Granulomatous focus in subcortical white matter of cerebral hemisphere containing three segments of the coiled nematode. 


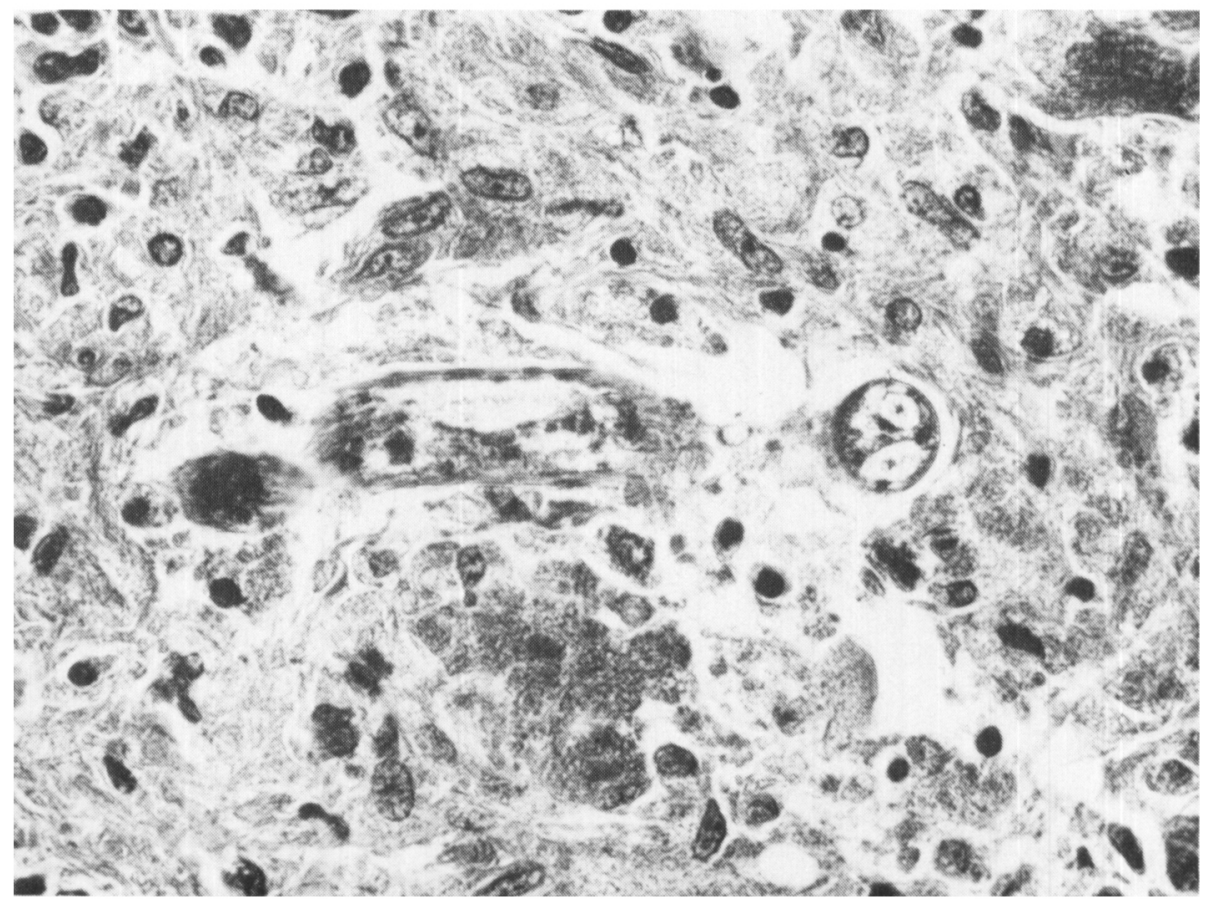

Figure 4. Higher magnification of Fig. 3 showing sections through the isthmus, gastroesophageal junction and midgut level of Toxocara canis larva.

HPS x 480 .

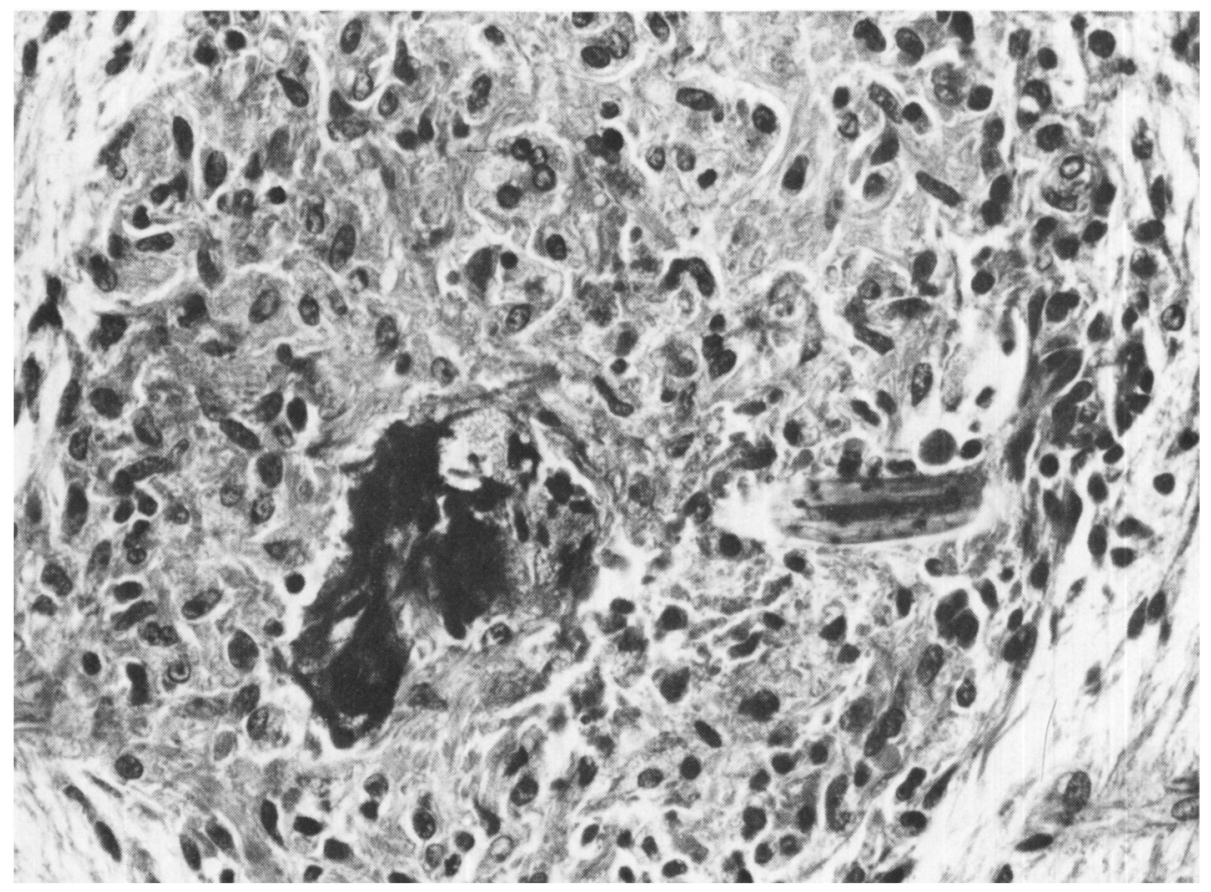

Figure 5. Granuloma in the cerebral white matter containing deeply staining cellular debris and a section through the esophageal end of the larva.

HPS x 300 .

McKee in 1957 and one case by Wong and Laxdal in 1958. None of these was histologically verified.

THE PARASITE

Toxocara parasites are widely distributed throughout the semitropic and temperate zones. The incidence of infestation in dogs fluctuates with seasonal variations (Ehrenford, 1957) but in general Toxocara is more prevalent in warm climates than in extreme northern areas. In the Northwest Territories Toxocara is rarely found (Unrah et al, 1973); (Webster, 1958). The prevalence of intestinal infestation in dogs in different countries varies from $2.5 \%$ to 93\% (Table 1), the prevalence being higher among puppies below 6 months of age. The prevalence in Canada varies from $8 \%$ to $88 \%$ (Table II).

The original identification of the parasite, Toxocara canis, is attributed to Werner in 1782 , but it was not until 1958 that the full development of these worms was studied by Sprent. Adult toxocaral worms measure 7.5 to $12.5 \mathrm{~cm}$ in length and are of no practical importance in human infection. The eggs measure $90 \times 75$ micra and have finely pitted shells. The ovum takes up to three weeks to develop into an infective larva in a suitable environment and remains viable for several months. The larva is a coiled helminth measuring 357 to 445 micra in length and 18 to 22 micra in diameter. The structural characteristics of the larva were studied in detail by Nichols (1956). The differentiation between Toxocara canis and certain other nematodes of similar size is made on the basis of transverse sections at the midgut level. The diagnostic features of Toxocara canis larva are as listed above. The infective second stage Toxocara canis and cati larvae have almost identical morphology, differing only in their maximum diameter, with Toxocara cati measuring 15 to 17 micra.

\section{LIFE CYCLE}

The life cycle is comparable to that of Ascaris lumbricoides and has been described in detail by Sprent (1958), and Brain and Allan (1964). In the natural host, the dog, the cycle varies according to the age and sex of the animal. Puppies are invariably infected pre-natally via the placenta. At birth, larvae are found in their lungs. These migrate to the trachea, are swallowed, and, upon reaching the upper gastro-intestinal tract mature into adult worms. By the time the puppy is about 3 weeks old eggs are excreted in enormous numbers. This massive excretion continues until the adult worms die, when the puppy is about 6 months old. Ex- 
TABLE 1

PREVALENCE OF TOXOCARA CANIS INFESTATION IN VARIOUS COUNTRIES

\begin{tabular}{lll} 
Countries & \% Infested Dogs & Investigators \\
\hline Mexico (Mexico City) & $93 \%$ of 120 dogs & Styles 1967 \\
India (Calcutta) & $82.8 \%$ of 100 dogs & Maplestone \& Bhaduri 1940 \\
Sicily & $79.5 \%$ Gallo \& Girolamo 1960 \\
Philippines (Manila) & $76.5 \%$ of 81 dogs & Yutuc 1954 \\
U.S.A. (New York State) & $73 \%$ of 64 dogs & Styles \& Evans 1971 \\
England (Cambridge) & $70.8 \%$ & Nuttal \& Strickland 1908 \\
Nigeria (Ibadan) & $37.5 \%$ of 72 dogs & Wiseman \& Woodruff 1971 \\
Malta & $28.8 \%$ of 52 dogs & Wiseman \& Woodruff 1971 \\
Tanzania (Dar-es-Salaam) & $28 \%$ of 50 dogs & Wiseman \& Woodruff 1971 \\
Australia (Melbourne) & $21.8 \%$ of 174 dogs & Pullar 1946 \\
U.S.A. (Indiana) & $21 \%$ of 1,465 dogs & Ehrenford 1957 \\
Spain (Madrid) & $21 \%$ & Millan 1959 \\
U.S.A. (Boston) & $20 \%$ & Heiner \& Kevy 1956 \\
Iraq (Bagdad) & $18.4 \%$ & Al-Safaar et al 1962 \\
Wales (Abereswyth) & $16.3 \%$ & Lewis 1927 \\
Chile & $15 \%$ & Neghme et al 1956 \\
France (Marseille) & $13.5 \%$ & Solomon 1933 \\
Uganda (Kampala) & $12.5 \%$ of 116 dogs & Wiseman \& Woodruff 1971 \\
Kenya (Nairobi) & $5.7 \%$ of 35 dogs & Wiseman \& Woodruff 1971 \\
England (London) & $2.5 \%$ of 161 dogs & Woodruff 1970 \\
\hline
\end{tabular}

TABLE II

\section{PREVALENCE OF TOXOCARA CANIS IN DOGS IN CANADA}

\begin{tabular}{|c|c|c|}
\hline Province & $\%$ Dogs Infested & Remarks \\
\hline Newfoundland* & $40 \%$ of $200 \mathrm{dogs}$ & (35\% pups 3 months of age) \\
\hline Nova Scotia* & $18 \%$ of 385 dogs & (13\% pups 3 months of age) \\
\hline New Brunswick* & $20 \%$ of 204 dogs & (18\% pups 3 months of age) \\
\hline $\begin{array}{l}\text { Quebec (St. Hyacinthe)* } \\
\text { (Montreal)** }\end{array}$ & $\begin{array}{l}35 \% \text { of } 211 \text { dogs } \\
52.6 \% \text { of } 155 \text { dogs }\end{array}$ & ( $14 \%$ pups 3 months of age) \\
\hline $\begin{array}{l}\text { Ontario* } \\
\text { (Ottawa Carleton Dog }\end{array}$ & $22 \%$ of 448 dogs & ( $13 \%$ pups 3 months of age) \\
\hline $\begin{array}{l}\text { Pound)*** } \\
\text { (Guelph)**** }\end{array}$ & $\begin{array}{l}51 \% \text { of } 51 \text { dogs } \\
88 \% \text { of } 1,000 \text { dogs }\end{array}$ & $\begin{array}{l}\text { (all pups } 3 \text { months of age) } \\
\text { ( } 80 \% \text { pups below } 6 \text { mos. age) }\end{array}$ \\
\hline Manitoba* & $8-10 \%$ & $\begin{array}{l}\text { (Majority pups) } \\
\text { Vet clinics }\end{array}$ \\
\hline Saskatchewan* & $15 \%$ & $\begin{array}{l}\text { ( } 30 \% \text { pups } 3 \text { months of age) } \\
\text { VSB Laboratory }\end{array}$ \\
\hline Alberta* & $10 \%$ & $\mathrm{U}$ of $\mathrm{A}$. Vivarium \\
\hline
\end{tabular}

* Survey of Veterinary Service Branch Provincial Department of Agriculture 1973 (Personal Communications).

** Choquette L.P.E. and Gélinas L. de G., C. J. of Comp. Med. 14: 33, 1950.

*** Survey by H. C. Rowsell, Veterinary Service Branch Lab. Ministry of Agriculture \& Food, Kempville, Ontario, Canada.

**** Lautenzlager J. P., Guelph, Ontario (Personal Communications).

creted eggs can remain viable in the soil for a year if protected from sunlight, freezing and drying (Dorman et al, 1958.)

When the eggs are ingested by adult dogs, the larva migrate through the body and can live in various tissues for long periods.

When the eggs are ingested by man, they hatch in the small intestine and the larvae migrate. Apparently, they are particularly active borers
(Sprent, 1958) and wide dissemination may occur via the blood stream and lymphatics. Larvae can remain viable in the tissues of man for a year or more (Smith et al., 1955), but they eventually die. The granulomatous lesions then heal by fibrosis.

Certain features of the life cycle of Toxocara in its natural and unnatural hosts underscore two important aspects of visceral larva migrans in man. First, for humans to develop the infection, infective Toxocara ova from contaminated soil must gain access to the gastro-intestinal tract. Secondly, a search for Toxocara ova in the stools of an infected human will be fruitless since the larvae never mature in the tissues of a foreign host (Zinkham, 1968).

\section{CLINICAL PRESENTATION}

Visceral larva migrans is primarily a disease of small children, and a careful history frequently reveals pica. The history of pica is more important in establishing the source of infection than is the ownership of a cat or dog.

The clinical features of this syndrome depend on the number of larvae, the frequency of their migration, the organ involved and the host's sensitivity to the Toxocara (Shrand, 1964). Symptoms include fever, irritability, pallor, anorexia and malaise. Hepatomegaly is the most common physical finding, varying in amount. Splenomegaly is less often observed, and when present tends to be minimal. Abnormalities of the lungs are common, and physical examination of the chest may reveal signs compatible with bronchitis, asthmatic bronchitis or bronchopneumonia. In many patients the pulmonary changes tend to recur.

Eye symptoms and signs have long been recognized (Ashton, 1960; Nichols, 1956; Wilder, 1950) and findings resembling retinoblastoma and chronic endophthalmitis have been well documented.

A toxocaral larva was found in the myocardium of a patient by Dent et al (1956), and Friedman and Hervada (1960) reported a case in which the circumstantial evidence for the myocarditis was strong. Woodruff (1965) suggested that involvement of the myocardium plays a part in the production of the puzzling endomyocardial fibrosis reported from Africa in recent years.

It is well known that a variety of neurological symptoms can develop in persons harbouring intestinal nematodes (Chalgren et al., 1946). The pathogenesis of these manifestations is obscure. It has been suggested that the symptoms are due to 
the effects of toxins or allergins originating from the parasites (Sprent, 1955 I \& II). To date, there are only four reported cases of human cerebral involvement by Toxocara canis (Beautyman et al, 1951, 1966; Dent et al, 1956; Moore, 1962; Schochet, 1967).

\section{DIAGNOSIS}

Diagnosis is suspected by the clinical features of the disease in association with persistent eosinophilia. Presumptive diagnosis may be made from the Toxocara skin test (Woodruff, 1966 and 1970). The skin test does not distinguish between infections which are recent and active and those which are long-standing and inactive. Active infections may be detected by a fluorescent-antibody test (Bisseru et al, 1968; Mitchell, 1964) or by hemagglutination techniques (Aljeboori et al, 1970; Kagan, 1958). The degrees of specificity of these tests are not entirely clear. Toxocara and ascaris species share many antigenic components and thus cross reactions occur.

For diagnosis to be made with certainty, one transverse section of the larva at the level of the midgut should be demonstrated in the tissues (Nichols, 1956).

\section{PROGNOSIS AND TREATMENT}

Visceral larva migrans is usually a relatively benign disease, although there is direct tissue damage by the migrating larvae and an allergic response to the parasite products. However, its severity varies with the number of larvae in the tissues and with the immune or allergic state of the individual (Beaver et al, 1952). In heavy infestation it is a serious disease, capable of producing blindness (Ashton, 1960; Wilder, 1950; Woodruff et al, 1964), pulmonary distress (Nichols, 1956) central nervous system disturbance (Beautyman et al, 1966, 1951; Dent et al, 1956; Moore, 1962; Schochet, 1967) and death (Brill et al, 1953; Schochet, 1967).

The treatment of infested individuals is uncertain, but diethylcarbamazine has in some cases led to regression of signs and symptoms
(Snyder, 1961), and in others the improvement has coincided with the fall in the titre of the fluorescentantibody test. The dose recommended is $3 \mathrm{mg}$ per $\mathrm{Kg}$ body weight twice daily for 21 days (Woodruff, 1966).

Aur et al (1971), reported rapid clinical and laboratory improvement in three children with visceral larva migrans following treatment by thiabendazole. Infected animals may be effectively treated by piperazine adipate; $200 \mathrm{mg}$ per $\mathrm{Kg}$ removes the majority of worms even in puppies (Sprent, 1958) although frequent repetition of treatment during the first six months of life is necessary. There is little doubt that effective deworming of animals will do more than any other single measure to reduce the incidence of infestation in man of this disease which is difficult to diagnose, and variable in response to treatment (The Lancet, 1972).

\section{REFERENCES}

ALJEBOORI, T. I., IVEY, M. H. (1970). An improved hemagglutination technique for detecting antibody against Toxocara canis. American Journal of Tropical Medicine and Hygiene, 19, $244-248$.

AL-SAFAAR, A. S. et al (1962). The Zoonosis of animal parasites in Iran. III The dog as a reservoir for human nematode infections. Bulletin of Endemic Diseases, $4,1-17$.

ASHTON, N. (1960). Larval granulomatosis of the Retina due to Toxocara. British Journal of Ophthalmology, 44, 129 - 148.

AUR, R. J., PRATT, C. B., and JOHNSON, W. W. (1971). Thiabendazole in Visceral Larva Migrans. American Joumal of Diseases of Children, 121, $226-229$.

BEAUTYMAN, W., BEAVER, P. C., BUCKLEY, J. J. C., and WOOLF, A. L. (1966). Review of a case previously reported as showing an Ascarid Larva in the Brain. Journal of Pathology and Bacteriology, 91, 271 - 273.

BEAUTYMAN, W. and WOOLF, A. L. (1951). An Ascaris Larva in Brain in Association with Acute Anterior Poliomyelitis. Journal of Pathology and Bacteriology, 63, $635-647$.

BEAVER, P. C., SNYDER, C. H., CARRERA, C. M., DENT, J. H., and LAFFERTY, J. W. (1952). Chronic Eosinophilia due to Visceral Larva Migrans; report of 3 cases. Pediatrics, 9, 7 - 19.

BISSERU, B., WOODRUFF, A. W. (1968). The detection of circulating antibody in human toxocara infections using the indirect fluorescent antibody test. Journal of Clinical Pathology, 21, 449 - 455.
BRAIN, LORD and ALLAN, B. (1964). Encephalitis due to Infection with Toxocara Canis; report of a suspected case. Lancet 1, 1355 - 1357.

BRILL, R., CHURG, J., and BEAVER, P. C. (1953). Allergic Granulomatosis Associated with Visceral Larva Migrans: case report with autopsy findings of toxocara infection in a child. American Journal of Clinical Pathology, 23, 1208 - 1215.

CHALGREN, W. S., and BAKER, A. B. (1946). Tropical disease; involvement of nervous system. Archives of Pathology, 41, $66-117$.

DENT, J. H., NICHOLS, R. L., BEAVER, P. C., CARRERA, G. $M$. and STAGGERS, R. J. (1956). Visceral Larva Migrans with Case Report. American Journal of Pathology, 32, 777 - 803.

DORMAN, D. W., VAN OSTRAND, J. R. (1958). A survey of Toxocara Canis and Toxocara Prevalence in the New York City Area. New York State Journal of Medicine, 58, 2793 - 2795.

EHRENFORD, F. A. (1957). Canine ascariasis as a potential source of Visceral Larva Migrans. American Journal of Tropical Medicine \& Hygiene, 6, 166 - 170.

FRIEDMAN, S. and HERVADA, A. R. (1960). Severe myocarditis with recovery in a child with Visceral Larva Migrans. Journal of Pediatrics, 56, 91 - 96.

GALLO, C. and GIROLAMO, G. (1960). Atti della Societa Italiana delle Scienze Veterinairie, 14, 339.

HEINER, D. C. and KEVY, S. V. (1956). Visceral Larva Migrans: report of syndrome in 3 siblings. New England Journal of Medicine, 254, 629 - 636.

KAGAN, I. G. (1958). Hemagglutination tests with Ascaris Antigens. Journal of Immunology, 80, 396 - 399.

LEWIS, E. A. (1927). A study of the helminths of dogs and cats of Aberystwyth, Wales. Journal of Helminthology, 5, 171 . 182.

McKEE, J. A. (1957). Visceral Larva Migrans. Bulletin of the Hospital for Sick Children, (Toronto), 6, 43 - 46.

MAPLESTONE, P. A. and BHADURI, N. V. (1940). Helminth parasites of dogs in Calcutta and their bearing on human parasitology. Indian Journal of Medical Research, 28, 595 - 604 .

MILLAN, F. S. (1959). Contribution to the study of the parasitic helminths of domestic animals. Revista Iberica de parasitologia, 19, $25-68$.

MITCHELL, J. R. (1964). Detection of Toxocara Canis Antibodies with Fluorescent Antibody Technique. Proceedings of the study for Experimental Biology and Medicine, 117, 267 - 270.

MOORE, M. T. (1962). Human Toxocara Canis Encephalitis with Lead Encephalopathy. Journal of Neuropathology and Experimental Neurology, 21, 201 - 218.

NEGHME, A., RIVERA, G. F. and ALVAREZ, M. (1956). Parasitic zoonosis in 
stray dogs of the city of Santiago. Boletin Chileno de Parasitologia, 10, 73 - 75 .

NICHOLS, R. L. (1956). Etiology of Visceral Larva Migrans; Diagnostic Morphology of Infective Second-Stage Toxocara Larvae. Journal of parasitology, $42,349-362$.

NUTTALL, G. H. F. and STRICKLAND, C. (1908). Note on the prevalence of intestinal worms in dogs in Cambridge. Parasitology, 1, 261.

PULLAR, E. M. (1946). A survey of Vicorian canine and vulpine parasites. Australian Veterinary Journal, 22, 85 - 91.

SCHOCHET, S. S. (1967). Human Toxocara Canis Encephalopathy in a Case of Visceral Larva Migrans. Neurology, 17, 227 - 229.

SHRAND, H. (1964). Visceral Larva Migrans: Toxocara Canis Infection, Lancet 1, 1357 1359.

SMITH, M. H. D., BEAVER, P.C. (1955). Visceral Larva Migrans due to infection with dog and cat ascarids. Pediatric Clinics of North America, 2, 163 - 168.

SNYDER, C. H. (1961). Visceral Larva Migrans; Ten Years experience. Pediatrics, $28,85-91$.

SOLOMON, S. G. (1933). The helminth parasites of dogs in Marseilles. Journal of Helminthology, 11, 157 - 162.

SPRENT, J. F. A. (1955). On Invasion of the Central Nervous System by Nematodes. 1. The incidence and Pathological Signifi- cance of Nematodes in the Central Nervous System. Parasitology, 45, 31 - 40 .

SPRENT, J. F. A. (1955). On Invasion of the Central Nervous System by Nematodes. II. Invasion of the Central Nervous System in Ascariasis. Parasitology, 45, $41-55$.

SPRENT, J. F. A. (1958). Observations on the development of Toxocara Canis (Werner, 1782) in the dog. Parasitology, 48, 184 - 209.

STYLES, T. J. (1967). Incidence of Toxocara canis and other helminth parasites of dogs in Mexico City. Journal of Parasitology, 53, $822-823$.

STYLES, T. J. and EVANS, D. S. (1971). Intestinal parasites of dogs and cats in Schenectady County. New York State Journal of Medicine, 71, 2755 - 2757.

TOXOCARA, (Edit.), (1972). Lancet, 1, $730-732$.

UNRAH, D. H. A., KING, J. E., EATON, R. D. P. and ALLEN, J. R. (1973). Parasites of dogs from Indian settlements in Northwestern Canada; A survey with Public Health Implications. Canadian Journal of Comparative Medicine, 37, 25 - 32.

WEBSTER, G. A. (1958). A report on Toxocara Canis (Werner 1782). Canadian Journal of Comparative Medicine, 22, 272 - 279.

WILDER, H. C. (1950). Nematode Endophthalmitis. Transactions of the American Academy of Opthalmology and Otolaryngology, 55, 99 - 109.
WISEMAN, R. A. and WOODRUFF, A. W. (1971). Toxocariasis in Africa and Malta. The frequency of infection in host animals and its incidence and distribution in humans as revealed by skin sensitivity tests. Transactions of the Royal Society of Tropical Medicine \& Hygiene, 65, 439 - 449.

WOODRUFF, A. W. (1965). Pathogenicity of intestinal helminthic infections. Transactions of the Royal Society of Tropical Medicine \& Hygiene, 59, 585 - 606.

WOODRUFF, A. W. (1966). Infection with animal helminth as a factor in causing poliomyelitis and epilepsy. British Medical Journal, 1, 1576 - 1579.

WOODRUFF, A. W. (1970). Toxocariasis. British Medical Journal, 3, 663 - 669.

WOODRUFF, A. W. and THACKER, C. K. (1964). Infection with animal helminths. British Medical Journal, 1, 1001 - 1005.

WONG, L. C. and LAXDAL, O. E. (1958). Visceral Larva Migrans. Canadian Medical Association Journal, 78, 695 - 699.

YUTUC, L. M. (1954). The incidence and prepatent period of Ancylostoma caninum and Toxocara canis in prenatally infected puppies. Journal of Parasitology, 40, 18 19.

ZINKHAM, W. H. (1968). Visceral Larva Migrans due to Toxocara as a cause of Eosinophilia. John Hopkins Medical Journal, $123,41-47$. 